\title{
Influence of Training and Work Motivation toward Science Teachers' at Junior High Schools in Poso City
}

\author{
Indri Novayanti Gala \\ Universitas Sintuwu Maroso \\ Poso, Indonesia \\ indri_gala@yahoo.co.id \\ Achmad Ramadhan \\ Universitas Tadulako \\ Palu, Indonesia
}

\author{
Amram Rede \\ Universitas Tadulako \\ Palu, Indonesia
}

\begin{abstract}
The aim of this research is to analyze the influence of training and work motivation toward the performance of science teachers in Junior High Schools in Poso. This research is a descriptive quantitative research by using survey method conducted from October to December 2015 with 33 respondents. The data collecting was questioner and is analyzed by multiple regression. Base on hypothesis test found the value of Fcount $>$ Ftable or $4,978>3,316$, and the influence contribution percentage is $24,9 \%$. Hence, it can be concluded that training and work motivation can influence the performance of science teachers in Junior High Schools in Poso.
\end{abstract}

Keywords- Training; Work Motivation; Performance of Teachers

\section{INTRODUCTION}

The education process is a system consisting of input, process, and output. Input is a learner who will carry out learning activities, the process is an activity of teaching and learning while the output is the result of the process undertaken. From the implementation of the educational process is expected to produce quality human resources and highly competitive to face competition in the era of globalization.

Teachers as the educational staff are one of the determinants of the success of educational goals, because teachers are directly in contact with learners, to provide guidance that will produce the expected graduates. In the context of education, teachers have a very big and strategic role, because the teacher who is in the forefront in the implementation of education. Master who is dealing directly with learners to transfer science and technology as well as educate with positive values through guidance and exemplary [1].

The role and strategic position faced by teachers in improving the quality of human resources, demanding that teachers always improve their professional ability in carrying out their duties and obligations. That is, for the quality of their students increased, the quality of teachers also need to be improved. Being a teacher is a profession full of challenges because teachers are faced with the demands of professional quality, trust from parents, community, stakeholders, government and also because of teachers still considered to have accountability for the success of student academic learning [2].

The success of education in schools is determined by the teacher's own teaching performance. According to Subroto in [3], teachers' teaching performance is the ability or ability of teachers to create an educative communication atmosphere between teachers and learners that includes cognitive, affective and psychomotor moods as an effort to learn something based on planning up to evaluation stage and follow up achieve the purpose of teaching. The importance of teaching performance in improving optimal student learning outcomes is one of the external forces that can be used by a teacher to exercise his influence in teaching.

The motivation of work is one factor that contributes to determining the high performance of a teacher. In addition, work motivation causes a teacher to be passionate about teaching because he has fulfilled his needs. Motivated teachers will have a high responsibility to work with enthusiasm and as well as possible to mobilize all skills and skills in order to achieve optimal performance, especially with respect to students. This is in line with the opinion [4], that the fulfillment of material needs is the motivation of work that comes from outside the individual teacher but the effect on the condition of a teacher's psychological satisfaction.

Training is an activity that intends to improve and develop the attitude, behavior and skills and knowledge of the employee in accordance with the wishes of the organization. Training assumes the basis of formal education, training has the meaning of mastering certain skills both physical and mental academic skills are coveted in a particular profession [5].

Research related to this research is research conducted by [6], indicating that teaching experience, training, and work motivation influence to work behavior of Biology teacher. Demikiain also research conducted by [7], giving the result of education and training, compensation and job satisfaction of teacher influence to teacher performance. 
Based on the observations made in Junior High School in Poso city, it was found that teachers have tried to improve the quality of performance by attending the training, which when presented that $75 \%$ science teachers in junior high schools throughout Poso have attended training related to learning activities such as KBK Curriculum Training, KTSP and Curriculum 2013 and has gained guidance in order to increase work motivation. However, there are still some teachers who show low performance such as teachers without good preparation that does not make the administration of learning tools as a preparation material to teach or just deliver teaching materials and teaching in a monotonous manner. Similarly, the work motivation of science teachers in junior high schools in Poso city is still largely derived from extrinsic motivation ie the spirit of work when there is promotion, praise or prize. While the intrinsic motivation of teachers is still a small part found teachers who can improve the motivation of work such as the need for achievement. The condition of low teacher performance is of course also influenced by low teacher work motivation. Therefore, it is necessary to improve the teaching performance of teachers through educational activities and trainings as well as guidance on work motivation. Through these activities are expected to teach teacher performance will increase along with the better implementation of teaching and learning activities. This is in line with [8] opinion, that qualified teachers are customers/customers, many ways that individual teachers and institutions do to improve teacher quality through academic levels, training, performance incentives and so on.

Based on the above, the researcher wants to do research with the aim of: (1) to analyze the influence of training on teaching performance of science teachers in junior high school in Poso city, (2) to analyze work motivation on teaching performance of science teacher in junior high school Poso City, (3) to analyze the effect of training and work motivation on teaching performance of science teachers in junior high school in Poso City.

\section{METHODS}

The type of research used is descriptive quantitative. The quantitative descriptive research aims to describe and reveal to an object under study through sample data or population as it is [9] In this study, the results are processed and analyzed statistically to take conclusions. By using this research method will be known a significant influence between the variables studied, resulting in a conclusion that will clarify the picture of the object under study.

In this study the population consists of all science teachers who come from 10 schools (SMP Negeri and Private) in the city of Poso, amounting to 33 people. This study uses a sample of a population of 33 people, taking into account the feasibility of the data then all the population sampled.

Data collection techniques used a questionnaire consisting of training questionnaires, work motivation, and teacher teaching performance. Furthermore, the data were analyzed using linear regression analysis of simple and multiple using statistic test.

\section{RESULTS AND DISCUSSIONS}

The respondents of this research are from science teachers of junior high school in Poso city with 33 people. The data obtained from the results of the questionnaire analysis of training, work motivation and teacher teaching performance. The results of questionnaire analysis can be seen in Table I.

TABLE I. RESULTS OF TRAINING QUESTIONNAIRE ANALYSIS, WORK Motivation AND TEACHING PERFORMANCE OF TEACHERS

\begin{tabular}{|c|c|c|c|}
\hline \multirow[b]{2}{*}{ Respondents } & \multicolumn{3}{|c|}{ Score } \\
\hline & Training & $\begin{array}{c}\text { Work } \\
\text { Motivation }\end{array}$ & $\begin{array}{c}\text { Teaching Performance } \\
\text { Teachers }\end{array}$ \\
\hline 1 & 73 & 85 & 142 \\
\hline 2 & 72 & 87 & 140 \\
\hline 3 & 69 & 89 & 139 \\
\hline 4 & 73 & 84 & 141 \\
\hline 5 & 70 & 87 & 139 \\
\hline 6 & 76 & 79 & 140 \\
\hline 7 & 68 & 73 & 137 \\
\hline 8 & 72 & 80 & 142 \\
\hline 9 & 72 & 85 & 145 \\
\hline 10 & 69 & 88 & 141 \\
\hline 11 & 72 & 92 & 140 \\
\hline 12 & 73 & 85 & 142 \\
\hline 13 & 64 & 79 & 139 \\
\hline 14 & 74 & 83 & 140 \\
\hline 15 & 73 & 86 & 142 \\
\hline 16 & 76 & 84 & 143 \\
\hline 17 & 78 & 79 & 140 \\
\hline 18 & 66 & 76 & 139 \\
\hline 19 & 74 & 87 & 144 \\
\hline 20 & 67 & 79 & 137 \\
\hline 21 & 70 & 83 & 145 \\
\hline 22 & 71 & 85 & 143 \\
\hline 23 & 69 & 79 & 140 \\
\hline 24 & 74 & 77 & 145 \\
\hline 25 & 72 & 79 & 137 \\
\hline 26 & 70 & 88 & 143 \\
\hline 27 & 65 & 90 & 139 \\
\hline 28 & 68 & 86 & 145 \\
\hline 29 & 70 & 89 & 143 \\
\hline 30 & 76 & 90 & 146 \\
\hline 31 & 74 & 89 & 144 \\
\hline 32 & 69 & 85 & 143 \\
\hline 33 & 73 & 87 & 140 \\
\hline
\end{tabular}

\section{A. The first hypothesis}

Based on the result of calculation with statistic program obtained $t_{\text {count }}>t_{\text {table }}(2,215>1,696)$, so the first hypothesis that there is the influence of training to teaching performance of science teacher in the junior high school in Poso city accepted. The result of correlation analysis between training with teacher teaching performance is obtained $\mathrm{R}=0,370(\mathrm{RYX} 1=0,370)$ which can be interpreted that there is strong enough influence between training (X1) on teacher teaching performance (Y). Furthermore, R Square (co-matching correlation coefficient R) is 0.137 . This result gives meaning as contribution of variable $\mathrm{X} 1$ to $\mathrm{Y}=\mathrm{R} 2 \times 100 \%$ or $0,3702 \times 100 \%=13,7 \%$. While the remaining $86.3 \%$ is determined by other factors not included in this study. 


\section{B. The second hypothesis}

Based on the result of calculation with statistic program obtained $t_{\text {count }}>t_{\text {table }}(2,234>1,696)$, so the first hypothesis that there is an influence of work motivation to teaching performance of science teacher in the junior high school in Poso city accepted. The result of correlation analysis between work motivation and teacher teaching performance is obtained $\mathrm{R}=0,372$ ( $\mathrm{RYX} 2=0,372)$ which can be interpreted that there is strong enough influence between work motivation (X2) on teacher teaching performance (Y). Furthermore, R Square (correlation coefficient squaring $\mathrm{R}$ ) is 0.139 . This result gives meaning as contribution of variable $\mathrm{X} 2$ to $\mathrm{Y}=\mathrm{R} 2 \times 100 \%$ or $0,3722 \times 100 \%=13,9 \%$. While the remaining $86.1 \%$ is determined by other factors not included in this study.

\section{The third hypothesis}

Based on the result of calculation with statistic program obtained $F_{\text {count }}>F_{\text {table }}(4,978>3,316)$, so the third hypothesis that there is an influence of training and work motivation simultaneously to teaching performance of science teachers in the junior high school in Poso city accepted. The result of correlation analysis between training and work motivation with the teacher teaching performance obtained value $\mathrm{R}=0,499$ ( $\mathrm{RYX} 1, \mathrm{X} 2=0,499)$ which can be interpreted that there is strong enough influence between training (X1) and work motivation (X2) teacher teaching performance (Y). Furthermore, R Square (squaring R coefficient of correlation) is 0.249 . This result gives meaning as a contribution together variable $\mathrm{X} 1$ and $\mathrm{X} 2$ to $\mathrm{Y}=\mathrm{R} 2 \times 100 \%$ or $0,4602 \times 100 \%=$ $24,9 \%$. While the remaining $73.1 \%$ is determined by other factors not included in this study.

\section{RESUlT AND DiSCUSSION}

\section{A. The Influence of Training on Teaching Performance Teachers}

The test results on the effect of training on teacher teaching performance as described earlier proved that the training had a strong effect on the teaching performance of science teachers in the junior high school in Poso city. Based on these results, it can be argued that training is a requirement that must often be followed by a teacher in carrying out its duties in improving its performance in teaching. This is in line with research conducted by [10] that the results obtained are the training has a dominant influence on teacher performance and implies that the more teachers follow the relevant training, the better the performance of teachers.

The results showed that the training gave positive and significant influence to the improvement of teaching performance of science teachers in the junior high school in Poso City with the contribution of $13.7 \%$. It provides an illustration that training is one of the factors that support teacher teaching performance. Thus, improving teachers' performance in teaching can be done well if teachers often attend training related to improving the quality or performance of teachers in learning so that the quality of education will also increase. However, with the contribution of relatively small influence, it can be interpreted that training is not the main factor affecting teacher's teaching performance because $86.3 \%$ is influenced by other factors not specified in this research.

The training which was attended by teachers of science in junior high school in Poso city, the training that has been followed by science teacher of SMP in Poso city is good enough but the influence of training in improving teacher teaching performance is still in a very low category. This may be due to the lack of sensitivity of the teachers who have attended the training to apply the training results that have been followed in the lesson so that the learning process is not optimal and the participation of teachers in the training is not evenly distributed.

The results of this study give the meaning of the better the training will be the better the performance of science teachers in teaching. This is in line with [11] opinion, mentions high performing teachers will be passionate and try to improve their competence, both in relation to planning, implementation, and assessment of learning, to obtain optimal work results. Similarly, the opinion of [12] in his research reveals that there is a significant change for teachers who follow the training both from the category of knowledge and skills to be better so as to improve the quality of teachers is high.

\section{B. Influence Work Motivation on Teaching Performance Teachers}

Motivation is an important factor in human beings that play a role to generate spirit to achieve goals. The motivation of work is something that can generate the spirit or encouragement of working individuals or groups of workers to achieve goals. With the motivation of work, the teacher has the encouragement of the spirit both from within and outside himself to carry out the work in teaching and learning activities to achieve goals in accordance with the desired.

The results of this study indicate that the motivation of work affects the performance of science teachers in SMP Poso City. This is in line with the research presented by [13], which states that work motivation is summed up as a condition that has an effect on generating, directing and maintaining behavior related to work environment. Thus, it can be interpreted that motivation is one of the elements that shape the performance of teachers in carrying out their duties and responsibilities as a teacher. Similarly, the opinion [14] revealed the motivation of teachers can be interpreted as a mental impulse that is owned by a teacher is doing his job as a teacher. The motivation of teacher's work to make yourself a teacher to be the spirit to carry out the work in teaching and learning activities in order to achieve goals as planned.

The correlation with this research, the influence of work motivation on teacher teaching performance is $13,9 \%$ so it is categorized very low. Can be attributed to the lack of motivation from within the teacher (intrinsic motivation) to improve its performance in teaching so that work motivation arises when there is praise, reward or incentive of what it does.

School as a place where teachers carry out their duties should also continue to improve the motivation of teachers work by trying to meet the needs that can encourage teachers eager to work. Working with the hope of acquiring incentives, 
praise, and attention from leaders and co-workers are the factors that influence work motivation. However, every teacher should be encouraged to further improve his work motivation from within himself such as having responsibility, goals and task/target clearly and feelings of pleasure in work and desire to continue to achieve so that teachers will continue to improve their performance spirit. This is in line with [15] opinion, that the most successful work motivation is self-direction, where intrinsic motives are stronger than extrinsic motives.

\section{The Influence of Training and Work Motivation on Teaching Performance of Teachers}

The results of the research that have been described previously show that there are two factors related to the teaching performance of teachers either partially or simultaneously that is training (X1) and work motivation (X2). Training related to knowledge and ability in carrying out its work more effectively and efficiently. In addition, work motivation is needed because it can influence to generate, direct and maintain behavior related to work environment [16].

The results of data analysis and hypothesis testing showed that there is a significant effect of training and work motivation on teaching performance of science teachers in the junior high school in Poso city with contribution influence of $24.9 \%$ while the remaining $73.1 \%$ is influenced by other factors that are not determined in this study. This result is still greater than the contribution value of the effect of training and works motivation individually on teacher teaching performance. This means that training will further improve teacher's teaching performance is followed by high work motivation. This is in line with [8] opinion, that qualified teachers are the desire for the users/customers, many ways that individual teachers and institutions do to improve the quality of teachers such as through academic level improvement, training, performance incentives improvement and so on. In addition, many factors that can affect the performance of teachers include adequate and reasonable competence, safe and healthy working conditions, opportunities to develop skills, sense of belonging, work motivation, work discipline and others.

The relationship with this study, which shows the effect of training and work motivation on the teaching performance of science teachers in Poso City with contribution of influence of $24.9 \%$, should be able to provide excited stimulation especially science teachers in junior high school in Poso city to continuously improve their performance through his/her participation in relevant training and in accordance with the needs of the teachers, both within the scope of the school and the Education Office. Teaching performance will increase if each teacher who has attended the training is able to apply the training results that have been followed in the learning activities so that it will also affect the learning outcomes are increasing. As the opinion of Imron in [17], states that educators or teachers are the spearheads for the school in carrying out the process of learning activities. Therefore, the high level of student achievement cannot be separated from the performance of the teacher. To improve its performance, teachers should always try on time, using methods and strategies appropriately, training and so on so as to improve the quality of learning. Willingness to improve the performance, of course, must be supported by work motivation. Teachers who have high motivation will achieve high performance, and conversely, low-performing teachers are caused by low motivation as well. This suggests that work motivation is one of the factors that play a role in shaping the performance of teachers in carrying out their duties.

The result of hypothesis testing of this research is to reject $\mathrm{H} 0$ and receive $\mathrm{H} 1$. Thus, training and work motivation can improve teachers' teaching performance. Training can add skills, knowledge, and skills to work while work motivation will give encouragement to be more enthusiastic and earnest in work. Through training, it is expected that all the difficulties and problems faced by teachers in learning can be solved and also able to improve the quality of education in schools through improving the quality of learning. Good job motivation arises from the desire and high awareness in carrying out teaching tasks without other elements that result in teachers being forced to carry out teaching tasks. Therefore, it is necessary to support and the role of education office, the school and the commitment of the teacher earnestly in order to increase professionalism.

\section{CONCLUSIONS}

Based on the results of the research and hypothesis testing, it can be concluded that: (1) There is a significant influence of training on the teaching performance of science teachers in Junior High School Poso, (2) There is a significant influence of work motivation on teaching performance of science teachers in Junior High School Poso, (3) There is a significant influence of training and work motivation simultaneously on the teaching performance of science teachers in Junior High School in Poso City.

\section{RECOMMENDATIONS}

- Teachers especially science teachers in junior high schools throughout Poso City should attend the training in accordance with the discipline of science.

- The Department of Education and the principal as policymakers in the school optimize activities that can improve work motivation such as an award (reward) for teachers who excel so as to increase teacher work motivation.

- This study examines the effect of teacher training and work motivation on teachers' teaching performance. Therefore, it is necessary to do further research by adding other variables that may affect or have the relationship with teacher teaching performance.

\section{ACKNOWLEDGMENT}

The author realizes that in preparing this thesis thanks to the support, suggestions, and input from various parties. By him, with all the respect and thanks the author convey to $\mathrm{Mr}$. Achmad Ramadhan as the Chief Counselor and Mr. Amram Rede, as a member of the Advisory Team who has provided much input, guidance and direction so that the authors can complete this paper from the beginning until the preparation of this article worthy to be published and the whole family and all 
parties who support in prayer, energy, and spirit in the completion of writing this.

\section{REFERENCES}

[1] Sutikno, S. 2004. Menuju Pendidikan Bermutu. Mataram: NTP. Press.

[2] Sanaky, H. 2005. Sertifikasi dan Profesionalisme Guru di Era Reformasi Pendidikan. Jurnal Pendidikan Islam:1-13 . Jakarta: Jurusan Tarbiyah.

[3] Yogaswara. 2010. Kontribusi Manajerial Kepala Sekolah dan Sistem Informasi Kepegawaian terhadap Kinerja Mengajar Guru pada SMP Negeri di Kecamatan Purwakarta. Jurnal Penelitian Pendidikan 11(2): $62-76$.

[4] Gusti. 2012. Pengaruh Kedisiplinan, Motivasi Kerja, Dan Persepsi Guru Tentang Kepemimpinan Kepala Sekolah Terhadap Kinerja Guru SMKN 1 Purworejo Pasca Sertifikasi. Jurnal Penelitian: 1-12.

[5] Tilaar dan Suryadi. 2001. Analisis Kebijakan Pendidikan. Bandung: Remaja Rosdakarya.

[6] Nurhaidah. 2011. Pengaruh Pengalaman Mengajar Pelatihan, dan Motivasi Kerja Terhadap Perilaku Kerja Guru Biologi di SMA Neger se- Kota Palu. Tesis. Palu: Program Pascasarjana Universitas Tadulako Palu.

[7] Muklisoh, N. 2008. Pengaruh Pendidikan dan Pelatihan, Kompensasi dan Kepuasan Kerja Guru terhadap Kinerja Guru Madrasah Tsanawiyah
Swasta Kecamatan Bulakamba Bresbes. Tesis. Semarang: Program Pascasarjana Universitas Negeri Semarang.

[8] Yamin, M. 2010. Standarisasi Kerja Guru. Jakarta: Gaung Persada.

[9] Sugiyono. 2010. Statistika Untuk penelitian. Bandung: Alfabeta.

[10] Wardana. 2008. Analisis Pengaruh Motivasi Kerja, Disiplin Kerja, Pendidikan dan Pelatihan terhadap Kinerja Guru Sekolah Dasar Negeri di Kecamatan Gayungan Kota Surabaya. Jurnal Penelitian 2(1): 19-31.

[11] Mulyasa. 2009. Standar Kompetensi Dan Sertifikasi Guru. Bandung: Remaja Rosdakarya.

[12] Jahangir.S.F. 2012. In-Service Training: A Contributory Factor Influencing Teacher's Performance. International Journal of Academic Research in Progressive Education and Development. 1(1): 32-37.

[13] Rivai. V. 2008. Manajemen Sumber Daya Manusia untuk Perusahaan dari Teori dan Praktik. Jakarta: PT. Raja Grafindo Persada

[14] Hasibuan, M.S.P. 2009. Manajemen: Dasar, Pengertian, dan Masalah. Jakarta: Bumi Aksara.

[15] Uno. 2008. Model Pembelajaran, Menciptakan Proses Belajar Mengajar yang Kreatif dan Efektif. Jakarta: PT. Bumi Aksara.

[16] Mangkunegara. 2009. Evaluasi Kinerja Sumber Daya Manusia. Bandung: Refika Aditama.

[17] Septiana. 2013. Pengaruh Kepemimpinan dan Motivasi Kerja terhadap Kinerja Guru SMP Negeri Wonosari. Jurnal Pendidikan UNS 2(1): 107 118 